FOLIA POMERANAE UNIVERSITATIS TECHNOLOGIAE STETINENSIS

Folia Pomer. Univ. Technol. Stetin., Oeconomica 2017, 335(87)2, 283-292

Grażyna VOSS

\title{
OCENA NORM ETYCZNYCH W PRAKTYCE I DYDAKTYCE WEDŁUG STUDENTÓW Z WYBRANYCH WOJEWÓDZTW
}

\section{EVALUATION OF ETHICAL STANDARDS IN PRACTICE AND TEACHNIG BY STUDENTS WITH SELECTED VOIVODSHIPS}

Katedra Organizacji i Zarządzania, Uniwersytet Technologiczno-Przyrodniczy im. Jana i Jędrzeja Śniadeckich w Bydgoszczy, ul. Fordońska 430, 85-790 Bydgoszcz, e-mail: gvoss@wp.pl

\begin{abstract}
Summary. The educational process economics students includes classes in business ethics social responsibility and ethical standards in accounting. For students the knowledge and observance of ethical standards is a key element of education and business operation. The aim of this article is to present the results of tests on the observance of standards and the areas in which universities should conduct classes.
\end{abstract}

Słowa kluczowe: etyka, kodeksy etyczne, normy etyczne w rachunkowości, praktyczne i dydaktyczne aspekty etyczne.

Key worlds: ethics, codes of ethics, ethical standards in accounting, practical and educational aspects of the ethical.

\section{WSTĘP}

Problemy etyki biznesu, społecznej odpowiedzialności biznesu i etyki zawodowej stały się w ostatnich latach obszarem zainteresowań zarówno w aspekcie teoretycznym, jak i praktycznym. Ponadto stały się również elementem procesu dydaktycznego w edukacji formalnej i nieformalnej (na różnych etapach kształcenia). Początek XXI wieku jest okresem nowych wyzwań, poszukiwania lepszych i bardziej efektywnych metod oraz form kształcenia, a koncepcja uczenia się przez całe życie jest obecnie uważana za nieodzowny element rozwoju zawodowego i aktywnego uczestnictwa na rynku pracy (Prewysz-Kwinto i Voss 2013). Istotną rolę w tym odegrały wydarzenia gospodarcze związane z oszustwami finansowymi i zachowaniami niezgodnymi z prawem i naruszającymi normy społeczne. Chociaż zachowania takie nie są „wynalazkiem” XX wieku, stały się podstawą etyki (Hendriksen i Van Breda 2002), która wywodzi się z filozofii starożytnej Grecji i Rzymu. Zawężając obszar oddziaływania norm etycznych, warto zauważyć, że etyka biznesu dotyczy moralnego wymiaru działalności gospodarczej i stanowi zbiór standardów określających to, co w biznesie jest moralnie właściwe, a co nie (Klimczak 2003). Postrzeganie działalności gospodarczej przez pryzmat etycznego postępowania uczestników rynku doprowadził do opracowania i wprowadzenia przez przedsiębiorstwa kodeksów etycznych, które zawierają zasady, jakimi powinni się kierować kierownicy i pracownicy jednostek gospodarczych w procesie tworzenia kultury organizacyjnej jednostki. Procedury zawarte w kodeksach etycznych są sposobem 
przekazywania pracownikom informacji na temat obowiązujących w firmie norm i akceptowanych sposobów postępowania w dziedzinach kluczowych dla jednostki (Nakonieczna 2008). Stały się również podstawą do opracowania i wdrożenia kodeksów etyki zawodowej dla wybranych grup zawodowych. We współczesnym świecie istnieje potrzeba wdrażania w praktyce programów etycznych, wynikająca z konieczności wprowadzania do świata biznesu zasad etyki po to, aby biznes był prowadzony uczciwie (Karmańska 2007).

Wśród grup zawodowych podlegających osądowi etycznemu są pracownicy wykonujący zawód księgowego, ponieważ odpowiedzialność za prowadzenie ksiąg rachunkowych i przedstawianie wiarygodnych sprawozdań łączy się nierozerwalnie z etyką zawodową, opisaną w „Kodeksie zawodowej etyki w rachunkowości” (2012) opracowanym przez Komisję Zasad Etyki i Profesjonalizmu Zawodu Księgowego Rady Naukowej Stowarzyszenia Księgowych w Polsce. Kodeks ten stanowi zbiór zasad i wartości etyczno-moralnych oraz profesjonalnych, jakie powinny cechować osoby zajmujące się rachunkowością i dziedzinami pokrewnymi, a także postaw i zachowań oczekiwanych od osób wykonujących zawody zaufania publicznego, do których zaliczyć można księgowych, finansistów, doradców podatkowych, nauczycieli i wykładowców z wymienionych dziedzin (Garstka 2015). Biorąc pod uwagę aspekt praktyczny stosowania norm etycznych w biznesie, warto zastanowić się nad tym, w jaki sposób przebiega proces edukacji i jakie są oczekiwania studentów w zakresie przedstawiania norm etycznych oraz skutków nieetycznych zachowań w działalności gospodarczej.

Celem artykułu jest zaprezentowanie wyników badania ankietowego, mającego na celu określenie postrzegania norm etycznych i wykorzystania wzorców zawartych w kodeksach etyki w praktyce oraz sposobu kształcenia studentów kierunków ekonomicznych z 4 uczelni z województw pomorskiego i kujawsko-pomorskiego.

\section{MATERIA I METODY}

Badanie zostało przeprowadzone wśród studentów studiów niestacjonarnych z 4 uczelni (2 publicznych i 2 niepublicznych) na terenie województw pomorskiego i kujawsko-pomorskiego. Do udziału w badaniu zostały zaproszone osoby studiujące na kierunku finanse i rachunkowość, ekonomia i zarządzanie. Wszystkie osoby objęte badaniem w ramach realizacji programów kształcenia miały zajęcia z zakresu rachunkowości i sprawozdawczości finansowej. Przy czym wymieniany zakres tematyczny i liczba godzin nie były identyczne na poszczególnych kierunkach studiów. Badanie zostało przeprowadzone w okresie od 10 kwietnia do 7 lipca 2016 roku z wykorzystaniem metody ankietowej. Przekazane respondentom kwestionariusze ankiet składały się z dwóch części:

- pierwszej, obejmującej pytania, które dotyczyły oceny skutków społecznych wynikających z nieetycznych zachowań podmiotów gospodarczych oraz z oczekiwań studentów związanych z realizacją procesu dydaktycznego w ramach kierunku studiów;

- drugiej, tzw. metryczki, która miała dostarczyć podstawowe informacje dotyczące wieku i okresu zatrudnienia respondenta.

Pytania zawarte w kwestionariuszu badawczym miały charakter zamknięty lub otwarty. Część z nich wymagała udzielenia tylko odpowiedzi: tak albo nie. Jednak w większości pytań 
respondent był proszony o wybór jednego lub kilku wariantów spośród przedstawionych. Tam, gdzie to było możliwe i wydawało się zasadne, pozostawiano respondentom swobodę wyrażenia własnych opinii. Do opracowania wyników badania zostały wykorzystane metody statystyczne, ze szczególnym uwzględnieniem wskaźnika struktury.

Do udziału w badaniu przystąpiło 500 studentów, z czego tylko 476 osób poprawnie wypełniło kwestionariusz i zostało objętych badaniem. Dwadzieścia cztery kwestionariusze zostały odrzucone z powodu nieprawidłowego wypełnienia i braku odpowiedzi na część pytań.

Wśród respondentów, których kwestionariusze zostały poddane dalszej analizie, dominowały kobiety (319 osób), osoby w wieku 25 do 40 lat (268) i respondenci, których staż pracy w działach księgowości wynosił od roku do 5 lat (268 respondentów). Szczegółowe informacje o osobach biorących udział w badaniu przedstawiono w tab. 1.

Tabela 1. Charakterystyka respondentów

\begin{tabular}{|l|l|c|c|}
\hline \multicolumn{2}{|c|}{ Cecha } & N & Procent \\
\hline \multirow{2}{*}{ Płeć } & kobieta & 319 & 67,00 \\
\cline { 2 - 4 } & mężczyzna & 157 & 33,00 \\
\hline \multirow{3}{*}{ Wiek } & do 25 lat & 112 & 23,53, \\
\cline { 2 - 4 } & od 25 do 40 lat & 268 & 56,30 \\
\cline { 2 - 4 } & powyżej 40 lat & 96 & 20,17 \\
\hline \multirow{2}{*}{$\begin{array}{l}\text { Staż pracy w działach } \\
\text { księgowo-finansowych }\end{array}$} & brak doświadczenia & 45 & 9,45 \\
\cline { 2 - 4 } & do roku & 98 & 20,59 \\
\cline { 2 - 4 } & od roku do 5 lat & 221 & 46,43 \\
\cline { 2 - 4 } & powyżej 5 lat & 112 & 23,53 \\
\hline
\end{tabular}

\section{ZASADY ETYCZNE W RACHUNKOWOŚCI}

Przeprowadzone badanie zostało oparte na zasadach etycznych w rachunkowości, które, zgodnie z „Kodeksem zawodowej etyki w rachunkowości” (2012), odnoszą się do osób zajmujących się rachunkowością. Bez względu na miejsce zatrudnienia oczekuje się, że: (Kodeks zawodowej etyki..., www.skwp.pl):

- ich praca będzie przebiegać zgodnie ze standardami zawodowymi,

- celem ich pracy będzie osiągnięcie najwyższego poziomu jakości,

- ich praca zapewni rzetelność wyników.

Na podstawie norm etycznych i ze względu na funkcję, jaką pełnią w jednostce gospodarczej osoby odpowiedzialne za prowadzenie ksiąg rachunkowych i sporządzanie sprawozdań finansowych, powinny one cechować się (Nisengolc i Sasin 2005):

- obowiązkowością,

- uczciwością,

- fachowością,

- systematycznością,

- poczuciem odpowiedzialności,

- lojalnością wobec właściciela i kierownictwa jednostki.

Kodeks etyki zawodowej w rachunkowości precyzuje 9 zasad etycznych, którymi pracownicy powinni kierować się w swojej pracy. Zasady te (Kodeks zawodowej etyki w rachunkowości 2012) dotyczą: 
1) kompetencji zawodowych, określanych jako należyte przygotowanie zawodowe, ustawiczne poszerzanie i aktualizowanie wiedzy, doskonalenie zawodowych umiejętności i ich wykorzystanie zapewniające uczciwe i rzetelne wykonanie prac;

2) wysokiej jakości pracy polegającej na staranności i obiektywizmie, terminowości i fachowości oraz sprawności organizacyjnej powiązanej z realizacją potrzeb informacyjnych znajdujących się w zakresie kompetencji pracownika i możliwości rachunkowości;

3) niezależności zawodowej, polegającej na wyrażaniu opinii i nieuleganiu wpływom, a także dbałością o wizerunek zawodu;

4) odpowiedzialności za przygotowanie i prezentowanie informacji z zakresu rachunkowości w sposób zgodny z obowiązującym prawem, ze standardami zawodowymi i z normami etycznymi;

5) właściwego postępowania w relacjach z osobami, jednostkami i instytucjami powiązanymi zawodowo, opierającego się przy tym na szacunku, zrozumieniu, bezinteresowności, wspólnym zaangażowaniu i wymianie doświadczeń;

6) właściwego postępowania w przypadku sporów i sprzeczności interesów, z uwzględnieniem obiektywnych i kompromisowych rozstrzygnięć;

7) właściwego postępowania w szczególnych sytuacjach pojawiających się w jednostce prowadzącej rachunkowość, z uwzględnieniem zasady rzetelnego i wiernego obrazu oraz norm etycznych;

8) zachowania tajemnicy zawodowej przez przestrzeganie prawa zarządu jednostki do nierozpowszechniania znanych im informacji mających charakter wewnętrzny, gdy ich ujawnienie nie jest obowiązkowe w świetle prawa;

9) właściwego oferowania usług z dziedziny rachunkowości poprzez działalność marketingową w zakresie pozyskiwania odbiorców usług z dziedziny rachunkowości.

Przedstawione w kodeksie zasady odnoszą się przede wszystkim do kompetencji zawodowych, wiedzy z rachunkowości i dziedzin pokrewnych oraz przestrzegania norm etycznych (Voss 2016). Zostały w nich szczególnie podkreślone rzetelność, odpowiedzialność, niezależność, terminowość i obiektywizm. Ponadto w realizacji przedstawionych zasad istotną rolę odgrywa kierownik jednostki jako osoba kompetentna, posiadająca odpowiednią wiedzę, przestrzegająca norm etycznych i ponosząca odpowiedzialność za wykonywanie obowiązków w zakresie rachunkowości, określonych w art. 4 ust. 5 Ustawy z dnia 29 września 1994 r. o rachunkowości, w tym także $z$ tytułu nadzoru. Znajomość i postrzeganie zachowań etycznych i nieetycznych przez studentów pozwala na ocenę procesu edukacyjnego i jego roli w kształtowaniu postaw etycznych wśród studentów - potencjalnych pracowników księgowości.

\section{WYNIKI}

Analizę otrzymanych odpowiedzi rozpoczęto od ustalenia, czy zdaniem respondentów zjawiska nieetyczne i zachowania z tym związane występują obecnie w gospodarce i czy mają one charakter powszechny; uzyskane wyniki zaprezentowano na ryc. 1. 


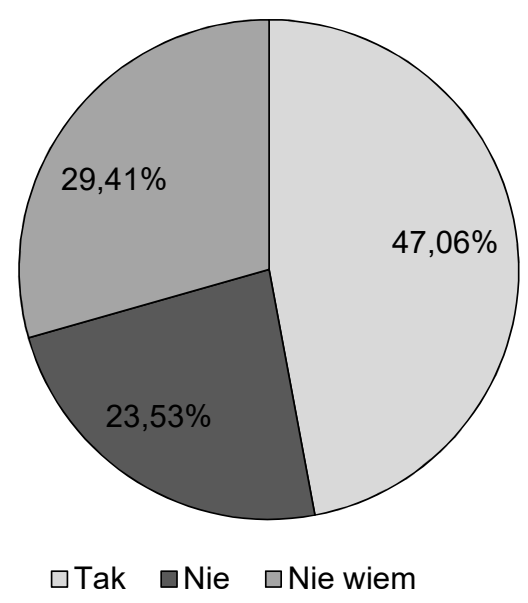

Ryc. 1. Występowanie zachowań nieetycznych w gospodarce Źródło: opracowano na podstawie ankiety.

Przedstawione wyniki wykazują, że prawie połowa ankietowanych (ponad 47\%) uważa, że zachowania nieetyczne są zjawiskiem powszechnym i że można je obserwować we współczesnej gospodarce i w relacjach zachodzących pomiędzy podmiotami i otoczeniem. Co trzeci respondent (29: 41\%) nie wie, czy badane zjawiska występują w praktyce. Brak informacji na temat naruszenia powszechnie stosowanych norm etycznych może być spowodowany niedostatkiem wiedzy na temat nieetycznych zachowań, jak również niewystarczających umiejętności, potrzebnych do rozpoznania, zidentyfikowania i oceny stosowania norm etycznych w praktyce.

Respondentów zapytano też, czy w życiu codziennym i pracy zawodowej spotkali się z zachowaniami nieetycznym w zakresie rachunkowości; uzyskane wyniki zostały przedstawione na ryc. 2.

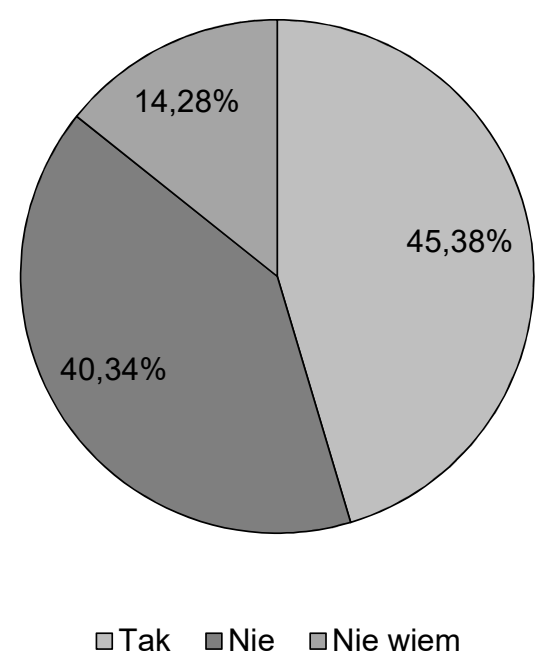

Ryc. 2. Występowanie zachowań nieetycznych w zakresie rachunkowości Źródło: opracowano na podstawie ankiety. 
Rycina 2 wskazuje, że ocena występowania niepożądanych zachowań uległa minimalnej poprawie - tylko 45\% respondentów spotkało się w pracy zawodowej z nieetycznymi zachowaniami w rachunkowości, a 14\% respondentów nie wie, czy spotkało się z takimi zachowaniami. Jeśli uwzględni się strukturę odpowiedzi, to można uznać, że ponad $85 \%$ respondentów potrafić zidentyfikować etyczne i nieetyczne zachowania w rachunkowości. Jednak wskazane odpowiedzi nie pozwalają na określenie poziomu wiedzy i umiejętności niezbędnych do takiej oceny sytuacji gospodarczych.

W dalszej części kwestionariusza ankietowanym zadano pytanie, które z podanych zachowań wpływają na nieetyczne zachowanie (respondenci mogli wybrać więcej niż jedną odpowiedź). Wyniki zaprezentowano na ryc. 3. Jako główne przyczyny nieetycznych zachowań respondenci wskazali brak reakcji przedsiębiorstw i środowiska na nieetyczne zachowania (246 wskazań) oraz chęć kreowania lepszego wyniku finansowego (241 wskazań). Jako kolejne przyczyny 236 respondentów wskazało naciski kadry kierowniczej na osiąganie jak najlepszych wyników i wskaźników finansowych, a 214 respondentów wymieniło próbę ukrycia wcześniej popełnionych błędów. Najrzadziej za przyczynę nieetycznych zachowań badani wskazywali niewystarczającą autonomię głównego księgowego.

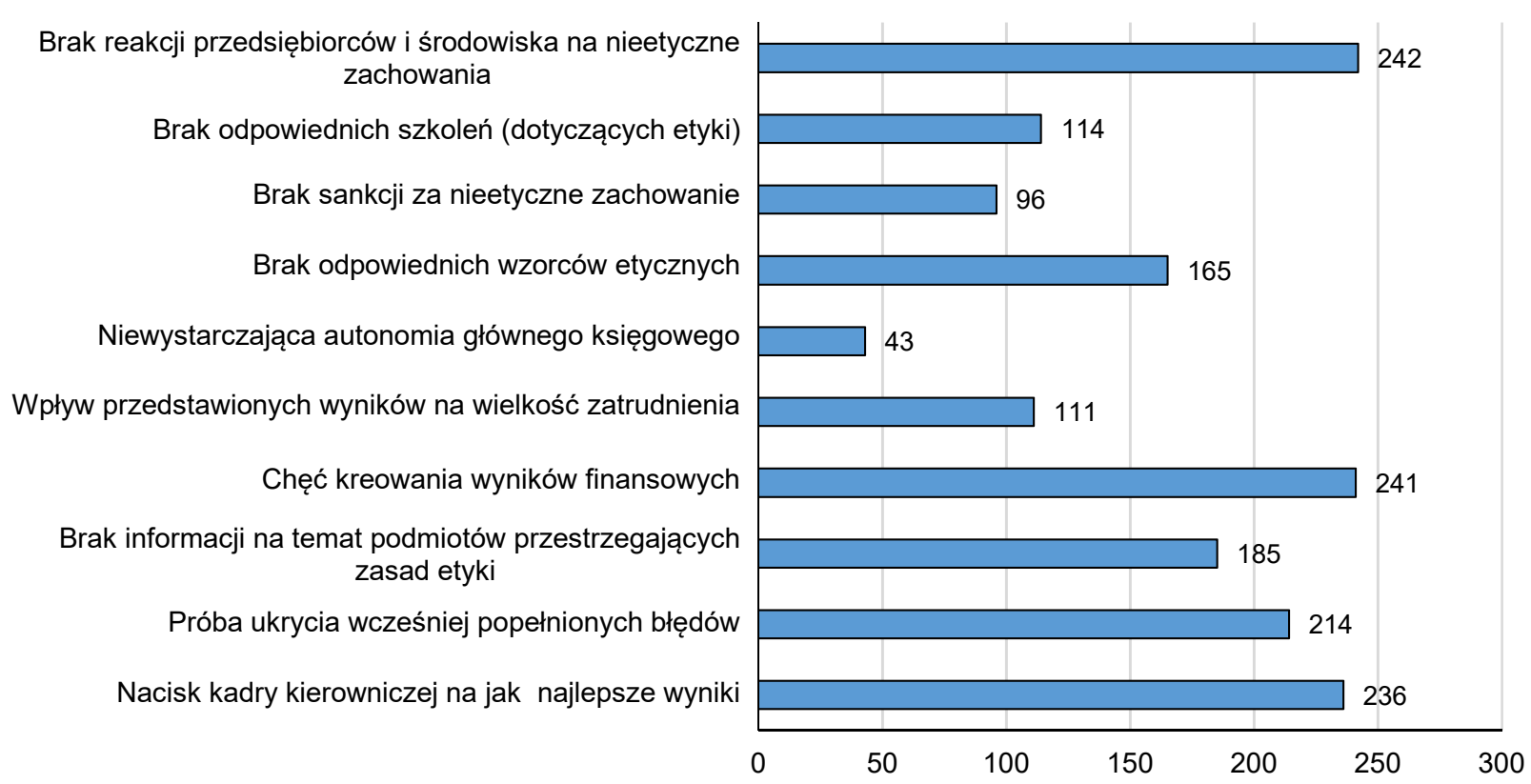

Ryc. 3. Przyczyny nieetycznych zachowań

Źródło: opracowano na podstawie ankiety.

Kolejne pytanie dotyczyło zasad wyboru kontrahentów, a zwłaszcza tego, czy firmy zatrudniające respondentów biorą pod uwagę informację dotyczącą postępowania kontrahentów w zakresie społecznej odpowiedzialności biznesu, etyki biznesu i przestrzegania zasad etyki w rachunkowości. Respondenci wskazali społeczną odpowiedzialność biznesu - 216 osób $(45,38 \%)$, przestrzeganie zasad etyki w rachunkowości - 84 osoby $(17,65 \%)$. Duży wpływ na udzielone odpowiedzi miała możliwość dostępu do niefinansowych informacji prezentowanych przez kontrahentów w raportach rocznych. 
Kolejne pytanie dotyczyło prezentowania przez podmioty gospodarcze informacji o przestrzeganiu zasad etyki w rachunkowości. Wyniki wielokrotnych wyborów odpowiedzi przez respondentów zaprezentowano w tab. 2.

Tabela 2. Prezentowanie w sprawozdaniu finansowym informacji dotyczących przestrzegania zasad etyki w rachunkowości

\begin{tabular}{|l|c|c|}
\hline \multicolumn{1}{|c|}{ Charakter prezentacji } & N & Procent \\
\hline Obligatoryjny dla wszystkich podmiotów & 356 & 74,79 \\
\hline Obligatoryjny dla dużych jednostek & 39 & 8,19 \\
\hline Dobrowolny dla wszystkich & 46 & 9,66 \\
\hline Dobrowolny dla małych podmiotów & 35 & 7,35 \\
\hline
\end{tabular}

Źródło: opracowano na podstawie ankiety.

Z tabeli 2 wynika, że zdaniem respondentów prezentacja informacji niefinansowych na temat przestrzegania norm etycznych w rachunkowości powinna być obligatoryjna dla wszystkich jednostek, a zwłaszcza dla jednostek zaliczanych do grupy dużych podmiotów gospodarczych. Jedynie co 10 ankietowany $(9,66 \%)$ uważa, że dobrym rozwiązaniem w tym zakresie byłoby indywidualne podejmowanie decyzji o informowaniu interesariuszy na temat wdrożenia i stosowania w jednostce gospodarczej zasad etyki w rachunkowości.

Mimo posiadanej wiedzy na temat stosowania norm etycznych w działalności gospodarczej ankietowani mieli możliwość również zaprezentowania swojej opinii na temat realizacji zajęć z zakresu norm etycznych $w$ trakcie studiów. Według respondentów szczególny nacisk powinien być położony na realizację zajęć z zakresu etyki zawodowej w rachunkowości $(40,13 \%)$ i etyki biznesu $(28,15 \%)$. Najrzadziej wymienionym obszarem była etyka zawodowa biegłych rewidentów (10,29\%). Wyniki badań przedstawiono w tab. 3.

Tabela 3. Przedmioty z zakresu etyki

\begin{tabular}{|l|c|c|}
\hline \multicolumn{1}{|c|}{ Zakres zajęć } & $\mathrm{N}$ & Procent \\
\hline Społeczna odpowiedzialność biznesu & 102 & 21,43 \\
\hline Etyka biznesu & 134 & 28,15 \\
\hline Etyka zawodowa w rachunkowości & 191 & 40,13 \\
\hline Etyka zawodowa audytorów & 49 & 10,29 \\
\hline
\end{tabular}

Źródło: opracowanie własne na podstawie badań.

Kolejne pytanie miało na celu uzyskanie opinii respondentów na temat zagadnień, które powinny być szczegółowo omawiane w trakcie zajęć. Ankietowani mieli możliwość zaznaczenia więcej niż jedną odpowiedź. Na szczególną uwagę zasługuje fakt, że we wszystkich proponowanych tematach liczba wskazań była zbliżona i wahała się od 151 do 178 - zob. ryc. 4 .

Ankietowanych poproszono również o wyrażenie opinii na temat, czy zajęcia edukacyjne prowadzone na studiach mogą oddziaływać na świadomość społeczną i właściwe postrzeganie norm etycznych w biznesie. W większości respondenci byli jednomyślni; 451 badanych odpowiedziało twierdząco, co stanowi $94,75 \%$ ankietowanych. 


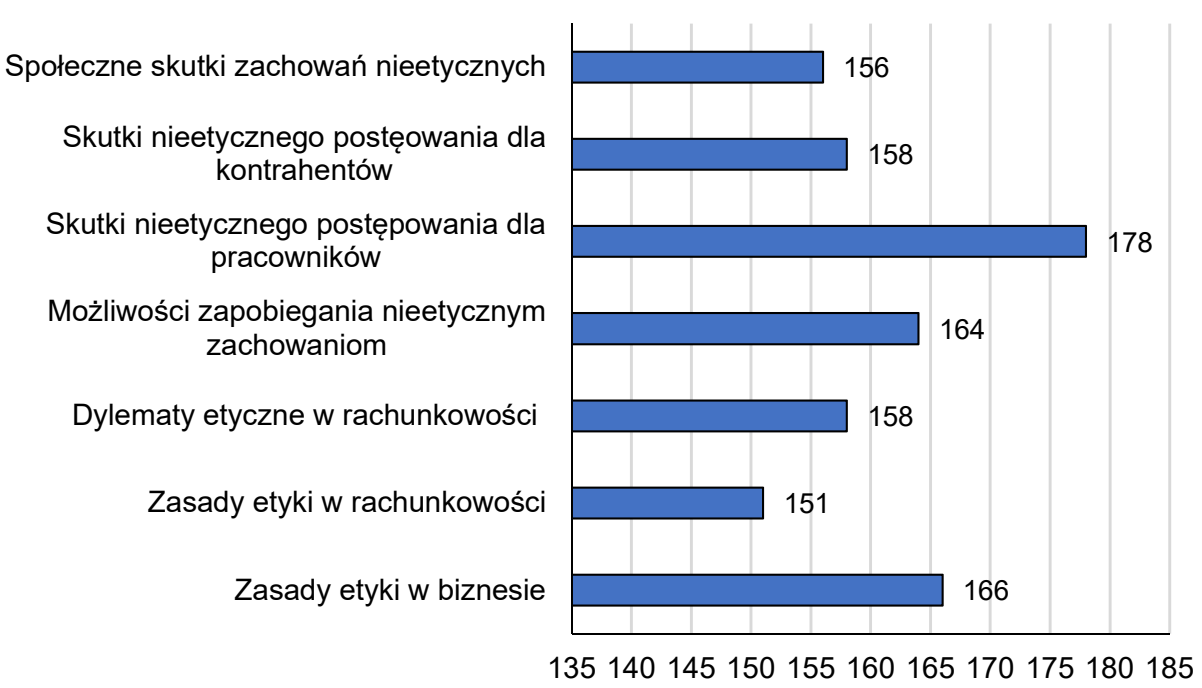

Ryc. 4. Zagadnienia z zakresu etyki wymagające szczegółowego omówienia Źródło: opracowano na podstawie ankiety.

Na podstawie przedstawionych wyników badań można stwierdzić, iż w grupie badanych potrzeba edukacji i przestrzegania norm etycznych stanowi ważny element zarówno w procesie edukacyjnym jak i w życiu gospodarczym.

\section{WNIOSKI}

Na podstawie ankiety, przeprowadzonej wśród studentów z wybranych kierunków studiów niestacjonarnych z województw pomorskiego oraz kujawsko-pomorskiego, dotyczącej postrzegania i stosowania norm etycznych w praktyce gospodarczej i w trakcie studiów, można sformułować następujące wnioski:

- prawie $50 \%$ badanych uważa, że zachowania nieetyczne są zjawiskiem powszechnym i można je obserwować we współczesnej gospodarce w relacjach zachodzących pomiędzy podmiotami i otoczeniem;

- 45\% respondentów spotyka się w pracy zawodowej z zachowaniami nieetycznymi w rachunkowości;

- główną przyczyną zachowań nieetycznych jest brak reakcji przedsiębiorstw i środowiska na nieetyczne zachowania, chęć kreowania lepszych wyników finansowych i naciski kadry kierowniczej na optymalizację wyników i wskaźników ekonomicznych;

- zdaniem respondentów niezbędna byłaby prezentacja informacji niefinansowych w sprawozdaniu na temat przestrzegania norm etycznych w rachunkowości, a także ujawnienie informacji na temat wdrożenia i wykorzystania kodeksu etyki zawodowej w rachunkowości i procedur kontrolnych związanych z przestrzeganiem norm etycznych;

- w zakresie edukacji należy położyć szczególny nacisk na skutki zachowań nieetycznych dla pracowników, kontrahentów i społeczeństwa oraz na możliwości zapobiegania zachowaniom nieetycznym.

Podsumowując przedstawione wyniki badań w kontekście procesu edukacji, warto zwrócić uwagę na ocenę efektów kształcenia w ramach pomiaru dydaktycznego i wyróżnić obszary oceny (tab. 4). 
Tabela 4. Zakres oceny efektów kształcenia w etyce zawodowej

\begin{tabular}{|l|l|l|}
\hline Lp. & Efekt kształcenia & \multicolumn{1}{|c|}{ Zakres oceny } \\
\hline \multirow{3}{*}{1} & \multirow{2}{*}{ Wiedza } & zna poszczególne zasady zawarte w kodeksie \\
\cline { 3 - 3 } 2 & \multirow{2}{*}{$\begin{array}{l}\text { Umiejętrafi zdefiniować zasadę i przedstawić różnice pomiędzy poszczególnymi } \\
\text { zasadami }\end{array}$} \\
\hline \multirow{2}{*}{3} & $\begin{array}{l}\text { W określonych sytuacjach ekonomicznych potrafi określić, jakie zasady zostały } \\
\text { naruszone oraz wskazać osoby, które doprowadziły do naruszenia zasad }\end{array}$ \\
\cline { 3 - 3 } & $\begin{array}{l}\text { kotrafi określić możliwości rozwiązania problemów związanych z naruszeniem norm } \\
\text { etycznych i wskazać sposób, w jaki należy się zachować w ramach przestrzegania } \\
\text { norm etycznych }\end{array}$ \\
\hline społeczne & $\begin{array}{l}\text { rozumie rolę etyki biznesu i etyki zawodowej w pracy i działalności gospodarczej } \\
\text { kowości dla pracowników, kontrahentów i środowiska lokalnego }\end{array}$ \\
\hline
\end{tabular}

Zaprezentowane zakresy efektów kształcenia w etyce zawodowej mogą dotyczyć zarówno zajęć z etyki biznesu, etyki w rachunkowości jak i społecznej odpowiedzialności biznesu.

\section{PIŚMIENNICTWO}

Garstka M. 2015. Etyka zawodu księgowego. Kielce, Wydaw. Uniw. J. Kochanowskiego, 18.

Hendriksen E. A., Van Breda M.F. 2002. Teoria rachunkowości. Warszawa, PWN, 237.

Karmańska A. 2007. Bezpieczeństwo biznesu, dylematy etyczne i profesjonalizm zawodu księgowego, w: Rachunkowość wczoraj, dzisiaj, jutro. Red. T. Cebrowska, A. Kowalik, R. Stępień. Warszawa, SKwP, 401.

Klimczak B. 2003. Etyka gospodarcza. Wrocław, Wydaw. AE Wroc. 81.

Kodeks zawodowej etyki w rachunkowości, http://www.skwp.pl, dostęp: 15.03.2015.

Kodeks zawodowej etyki w rachunkowości. 2012. Wyd. drugie. Warszawa, SKwP.

Nakonieczna J. 2008. Społeczna odpowiedzialność przedsiębiorstw międzynarodowych. Warszawa, Difin, 96.

Nisengole S., Sasin W. 2005. Vademecum finansisty i księgowego. Łódź, Agencja Wydaw. „Interfart” 20-24.

Prewysz-Kwinto P., Voss G. 2013. Metoda projektu według oceny studentów kierunków ekonomiicznych. Wyniki badania ankietowego. Folia Pomer. Univ. Technol. Stetin., Oeconomica 303(72), 157.

Ustawa z dnia 29 września 1994 r. o rachunkowości. DzU z 2015 r., poz. 1333.

Voss G. 2016. Kształtowanie norm etycznych a odpowiedzialność zawodowa księgowych. Bydgoszcz, Wydaw. Uniw. Technol.-Przyrod., 136. 
